\title{
AZ EGÉSZSÉGÜNKET MEGHATÁROZÓ TÉNYEZŐK BE- MUTATÁSA EGY LEHETSÉGES EGÉSZSÉGMODELL SEGÍTSÉGÉVEL
}

\section{ILLUSTRATING THE DETERMINING FACTORS OF OUR HEALTH WITH THE HELP OF A POSSIBLE HEALTH MODEL}

\author{
Dr. Bácsné dr. Bába Éva ${ }^{1}$, Müller Anetta ${ }^{1}$, Molnár Anikó ${ }^{1 *}$ \\ ${ }^{1}$ Sportgazdasági és -Menedzsment Intézet, Gazdaságtudományi Kar, Debreceni Egyetem, Magyarország \\ https://doi.org/10.47833/2021.1.ART.006
}

\author{
Kulcsszavak: \\ egészség \\ egészségben eltöltött életévek \\ egészségmodellek \\ egészségút \\ jóllét
}

\section{Keywords:}

health

healthy life years

health models

health-journey

well-being

\section{Cikktörténet:}

Beérkezett 2021. március 5.

Átdolgozva 2021. március 15.

Elfogadva 2021. április 2.

\begin{abstract}
Összefoglalás
Az egészség holisztikus megközelítése azt szemlélteti, hogy az ember egészségútja során egy sok tényezős rendszerben helyezkedik el, mely tényezők, és elemek az élete folyamán hatással vannak az egészségére, szubjektív jóllétére. A szakcikkben célunk a szekunder kutatásokon alapuló egészség-modellek bemutatása, majd egy saját modell szerkesztése, melyek elemeinek egészségre gyakorolt hatásait szekunder kutatásokkal igazoljuk. A modell az egyén egészségére ható külső (természeti és társadalmi környezet) és belső (genetika, életmód-elemek, szociális környezet) környezeti elemeket rendszerezi és mutatja be azok egészségben betöltött szerepét.
\end{abstract}

Abstract
The holistic approach of health shows, that a person's "health-
journey" is spent in a multifactored system, where different fac-
tors and elements affect the health and subjective well-being of
the individual. The aim of our article is the presentation of the
existing health models based on secondary research, and with
our own approach, the construction of a new health model, the
elements of which are justified by secondary research as well.
The model structures the external- (nature and community) and
internal (genetics, lifestyle, social environment) factors influenc-
ing individual health, while also presenting their role in it.

\section{Bevezetés}

Az egészség holisztikus megközelítése napjainkban egyre erösebben jelenik meg a különböző nemzetközi és hazai szakirodalmakban és kutatásokban [1][2][3][4][5][6]. Ezek az értelmezések azt is megerősítik, hogy az egészségi állapotunkra a különféle belső és külső tényezők folyamatosan hatnak, melyek vagy megerősítik ezt az egészségi állapotot vagy negatív irányba befolyásolják azt. Az egészség nem egy konstans állapot, amiért mindig kell tenni, így az egészség fenntarthatósága is a kutatások középpontjába kerül [7][8][9].

\footnotetext{
* Kapcsolattartó szerző.

E-mail cím: miller.e.annie@gmail.com
} 
Az egészség mellett a szubjektív jólétre irányuló kutatások [10][11][12][13][14] nem csak az egészséges, de a különböző betegségekkel küzdő célcsoportokkal is foglalkoztak.

Az egészséget vizsgálhatjuk a várható élettartam vagy a várható életévek számával, mely az EKSI Egészségtudományi Fogalomtára szerint „Azon évek száma, amelyet az adott évben születettek - feltéve, hogy minden, a halálozási viszonyokat befolyásoló körülmény változatlan marad átlagosan megélhetnek az adott év kor-specifikus halálozási viszonyai mellett". Hasonló fogalmi értelmezést találhatunk Johnston és munkatársai megfogalmazásában is [15].

A várható élettartam nem csak az egészségben, de a betegségben vagy egészségkárosodásban eltöltött életévek számát is tartalmazza, illetve az is kritikája lehet a mutatónak, hogy a születéskor várható élettartam nem modellezi igazán a társadalom egészségi állapotát. Az egészség értelmezése kapcsán relevánsabb az úgynevezett egészségben eltöltött életéveket (vagy más néven az egészségkárosodástól mentes várható átlag-élettartamot) mérni, ami ugyan egy összetettebb és bizonytalanabb mutató, ám több népegészségügyi tanulmányban irányadónak vélik és alkalmazzák [16].

Az orvostudomány és a technológia fejlődése egyre hosszabb életet biztosít, ám ezzel nem járt azonos arányú életminőség növekedés. Ebben a tekintetben ráadásul jelentős különbségek jelentkeztek az országok között, illetve országon belül regionális szinten is.

Igaz ugyan, hogy a várható élettartam tekintetében az utóbbi évtizedekben pozitív változásokat igazoltak, hiszen jelentősen nőtt mind a férfiak, mind a nők körében a várható élettartam, azonban számos egészségügyi mutató továbbra is kedvezőtlenül alakul. Magyarországot az EU-ban az egyik legrosszabb egészségi állapottal jellemzik és az elkerülhető halálozással rendelkező országok közé sorolják. Hazánkban a születésekor várható élettartam 5,1 évvel maradt el az EU27 átlagától 2009-ben.

A magyar lakosság egészségi állapota 1960-as évek óta bizonyos betegségek előfordulási gyakorisága miatt romló tendenciát mutat. Ennek a következményeként hazánk messze elmarad a fejlettebb egészségügyi kultúrával rendelkező országok mögött az Európai Unióban. A magyarok egészségi állapota sokkal rosszabb, mint ami a gazdasági fejlettség alapján elvárható. A halálozási ráta növekszik a viszonylag fiatalabb generációk között. A 40-64 éves munkavállalók, illetve a középkorú férfiak esetében a halálozási arány igen magas. Ezenkívül Magyarország továbbra is vezető szerepet tölt be az öngyilkosságok terén és az egészségre káros szenvedélybetegek aránya is igen magas a populációban. A rosszindulatú daganat által okozott halálozási arány az európai országok közül a legmagasabb Magyarországon [17]. Hazánkban igen magas az úgynevezett életmódfüggő betegségek prevalenciája.

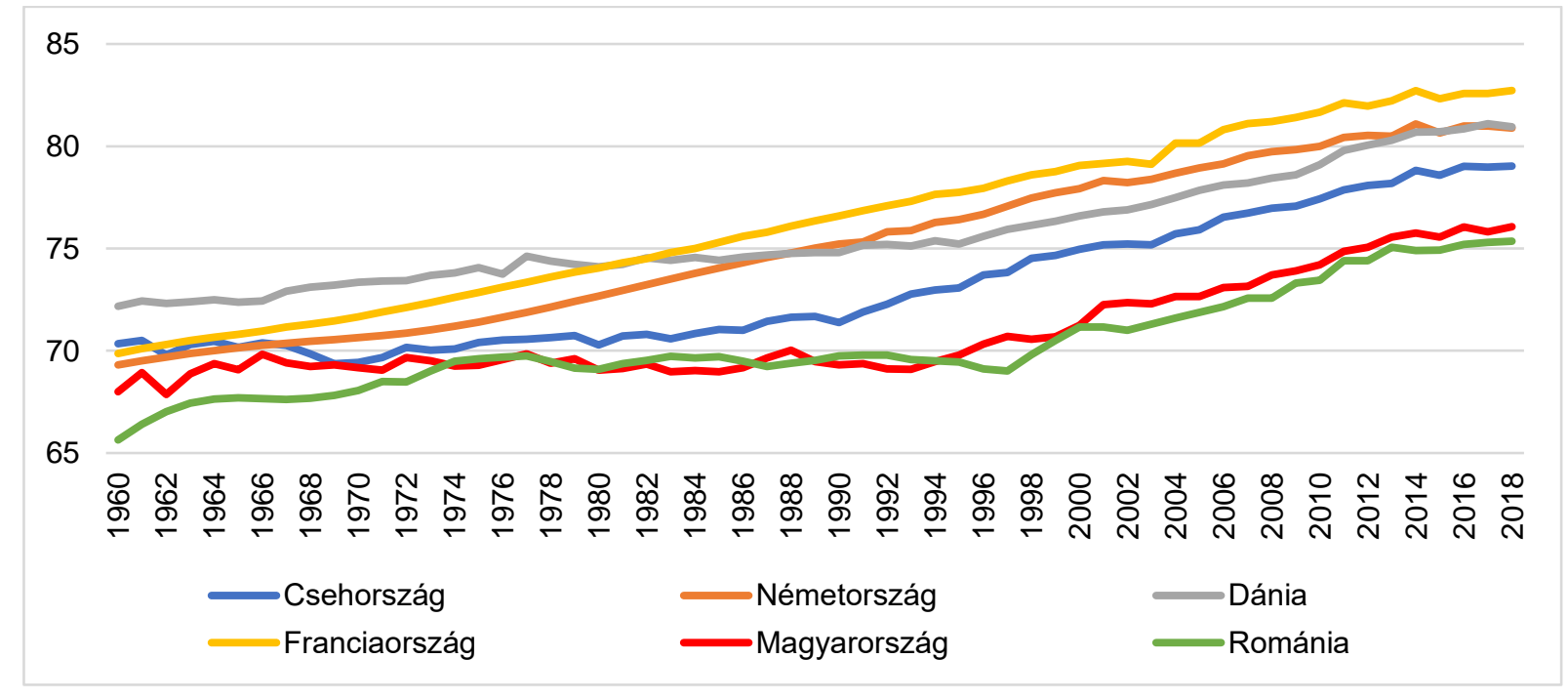

1. ábra. A várható átlagéletkor alakulása 1960-tól 2018-ig

Az 1. ábra szemlélteti, hogy míg 1990-ben 69 év addig 2018-ban Magyarországon már 76,06 év a születéskor várható átalagos élettartam, mely növekedést mutat. 2018-ban a nök esetében ez az adat 79,6év, míg a férfiak esetében csupán 72,7 év volt [18]. 
Amennyiben összehasonlítjuk hazánk adatait más európai országéval, úgy jól látszik, hogy Franciaországban, Németországban és Dániában 80 év felett várható a lakosság átlagéletkora mely jóval kedvezőbb a hazai adatoknál. Ugyanakkor a régiónkba tartozó Csehországban is megközelíti a 80 évet a várható átlagos élettartam, Romániában viszont alacsonyabb szinten realizálódik $(75,3$ év).

A WHO szerint Magyarországon 2000-ben a férfiak ELÉV-je (Egészségben eltöltött Életévek száma) 60 év a nőké 67 év volt, vagyis a teljes populációban átlagosan 63 év. Ebben is némi javulás figyelhető meg 2012-ben a férfiaké 63 évre, a nőké 69 évre, a teljes népességé pedig 66 évre növekedett [19].

Az átlagos élettartam igaz, hogy 76 év hazánkban, de ebből csupán 66 év az, amely elöreláthatóan egészségben telik el. Ennek a két adatnak közelíteni kellene egymáshoz oly módon, hogy az egészségben eltöltött életévek száma megközelítse a várható átlagos élettartamot. Ennek egyfajta lehetősége, ha az egészség-determinánsok tekintetében (külső és belső egészségre ható tényezők) tudunk olyan változásokat elérni, melyek az egészséget támogatják.

\section{Az egészség modellezés gazdaságtani megközelítése}

Az egészséggel kapcsolatos kutatási koncepciók közül sokan próbáltak modelleket alkotni, melyek különféle aspektusból közelítették meg a témát. Az egészség-modelleknek éppen ezért több típusa ismert, melyek valamely aspektus hatását elemzik az emberi egészséggel összefüggésben. A következőkben az egészség-gazdaságtani modellekből mutatunk be néhányat.

Az egészséggazdasági elemzéseknél a betegségteher, a klinikai vizsgálat mentén végzett gazdasági elemzés és a naturalisztikus egészség-gazdaságtani vizsgálatok alapján alakítottak ki modelleket [20].

1. Táblázat. Az egészséggazdasági-modellek csoportosítása és eredményeik

\begin{tabular}{|c|c|c|c|}
\hline $\begin{array}{l}\text { VIZSGÁLAT TÍ- } \\
\text { PUSA }\end{array}$ & SZERZŐ $(\mathrm{K})$ & $\begin{array}{l}\text { TERÜLET } \\
\text { VIZSGÁLAT }\end{array}$ & EREDMÉNY \\
\hline $\begin{array}{l}\text { Betegségteher } \\
\text { VIZSGÁLAT } \\
\text { Cost of illness } \\
\text { (COI) }\end{array}$ & $\begin{array}{l}\text { Ács et. al. } 2020 \\
\text { [21] }\end{array}$ & $\begin{array}{l}\text { A magyar fizikai inaktivitásból } \\
\text { eredö (szív és érrendszeri, } \\
\text { stroke, magas vérnyomás, vas- } \\
\text { tagbélrák, 2-es típusú diabé- } \\
\text { tesz, oszteoporózis, depresz- } \\
\text { szió, emésztőszerv-rendszeri, } \\
\text { obezitasz, magas triglicerid } \\
\text { szint, önártalom) betegségek } \\
\text { közvetlen és közvetett költsé- } \\
\text { geinek számítása 2009-2017 } \\
\text { közöttt }\end{array}$ & $\begin{array}{l}\text { 2005-ben ezen betegsé- } \\
\text { gek terhei (2017-es áron } \\
\text { )3753 milliárd Ft-ot tettek } \\
\text { ki, mely } 2009 \text {-ben } 3611 \\
\text { milliárdra csökkent, } 2014- \\
\text { ben } 2906 \text { milliárdra csök- } \\
\text { kent és } 2017 \text {-ben } 3220 \\
\text { milliárdra nött. }\end{array}$ \\
\hline $\begin{array}{l}\text { Betegségteher } \\
\text { VIZSGÁLAT } \\
\text { Cost of illness } \\
\text { (COI) }\end{array}$ & $\begin{array}{l}\text { Anis et. al. } 2010 \\
\text { [22] }\end{array}$ & $\begin{array}{l}\text { A kanadai lakosság túlsúlyából } \\
\text { és elhízásából eredő közvetlen } \\
\text { (2-es típusú cukorbetegség, } \\
\text { CAD betegség, magas vérnyo- } \\
\text { más, epehólyag betegség } \\
\text { emésztörendszert érintő daga- } \\
\text { natos megbetegedések, stb) és } \\
\text { közvetett költségek vizsgálata } \\
\text { 2006-ban }\end{array}$ & $\begin{array}{l}\text { 2006-ban az elhízásból } \\
\text { és túlsúlyból származó } \\
\text { közvetlen költségek } 6 \text { mil- } \\
\text { liárd \$ a közvetett költsé- } \\
\text { gek } 5 \text { milliárd \$-t }(1,8 \text { mil- } \\
\text { liárd \$ a túlsúlyból, } 3,2 \\
\text { milliárd \$) jelentettek }\end{array}$ \\
\hline $\begin{array}{l}\text { Betegségteher } \\
\text { VIZSGÁLAT } \\
\text { Cost of illness } \\
\text { COI }\end{array}$ & $\begin{array}{l}\text { Voigt et. al. } \\
2014 \text { [23] }\end{array}$ & $\begin{array}{l}\text { 2012-ben az USA-ban a lakos- } \\
\text { ság körében előforduló szív- } \\
\text { elégtelenségből származó köz- } \\
\text { vetlen költségek vizsgálata. }\end{array}$ & $\begin{array}{l}\text { közvetlen költségeket } \\
\$ 60.2-\$ 115.4 \text {, a teljes } \\
\text { költséget pedig } \\
\$ 70.8-\$ 127.0 \text { között álla- } \\
\text { pították meg. }\end{array}$ \\
\hline Klinikai vizsgálat & $\begin{array}{l}\text { Herczeg et. } \\
\text { al.2008 [24] }\end{array}$ & $\begin{array}{l}\text { Magyarországon az aszpirin } \\
\text { primer prevenció költségeit (te- } \\
\text { hát betegenként } 18708 \mathrm{Ft} \mathrm{öt}\end{array}$ & $\begin{array}{l}\text { Magyarországon várha- } \\
\text { tóan évente } 300000- \\
430.000 \text { fô kezelése. Egy }\end{array}$ \\
\hline
\end{tabular}




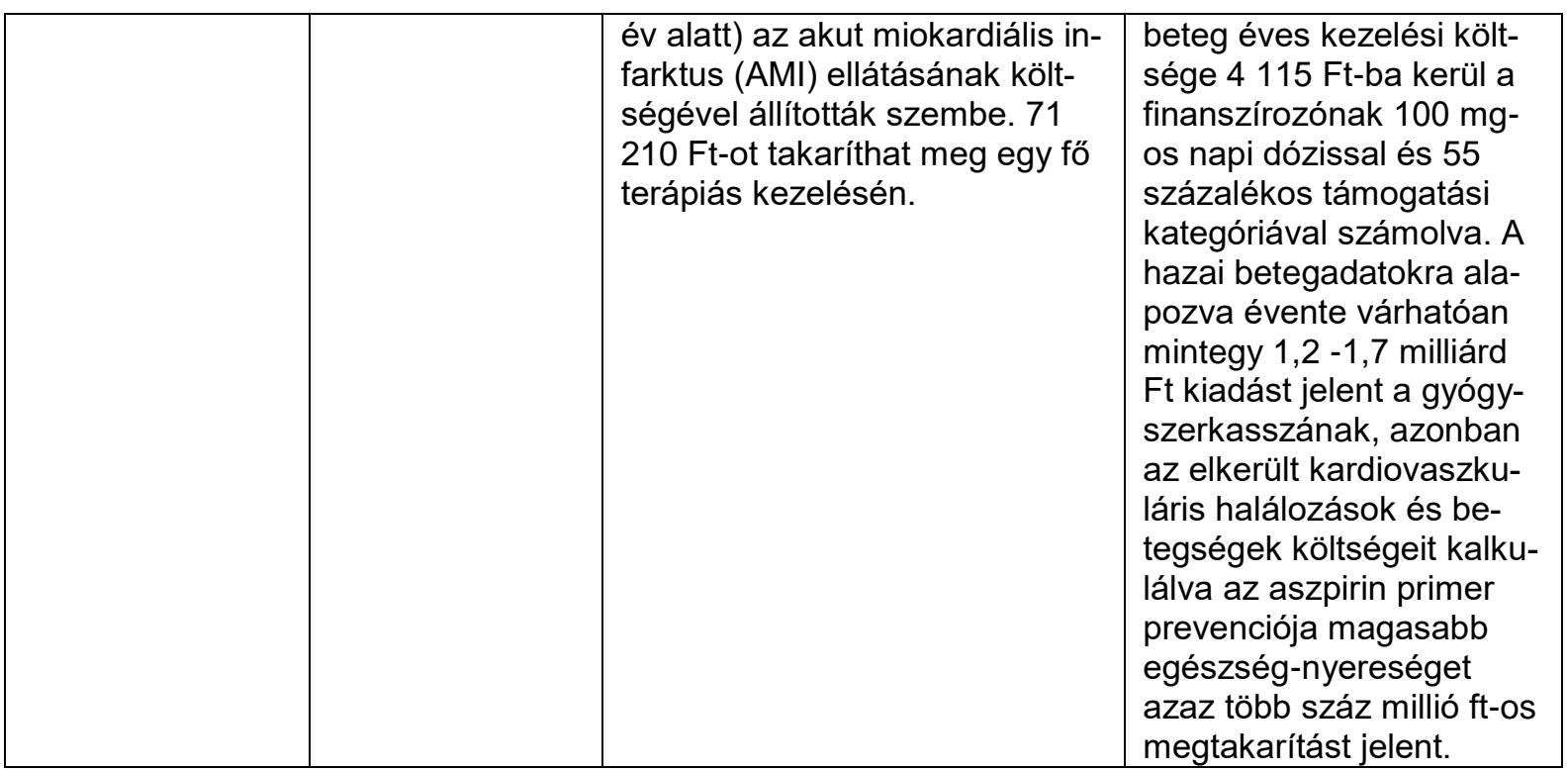

Az 1. táblázatban bemutatott egészség-modellek leginkább gazdasági jellegű megközelítéseket tartalmaznak, költség-haszon jellegű számításokon alapulnak, melyek az egészségre ható 1-1 tényezőt vizsgálva prognosztizálnak eredményeket, miközben feltételezik, hogy az emberre ható többi tényező konstans, azaz nem változik.

\section{Környezet által determinált egészség modell}

Célunk szekunder kutatás alapján önálló egészség-modell kialakítása, amely az egyén egészségére ható külső (természeti és társadalmi környezet) és belső (genetika, életmód-elemek, szociális környezet) környezeti elemeket rendszerezi és mutatja be azok hatását egészségben eltöltött évek esetében.

KÜLSỎ KöRNYEZETI DIMENZIÓK

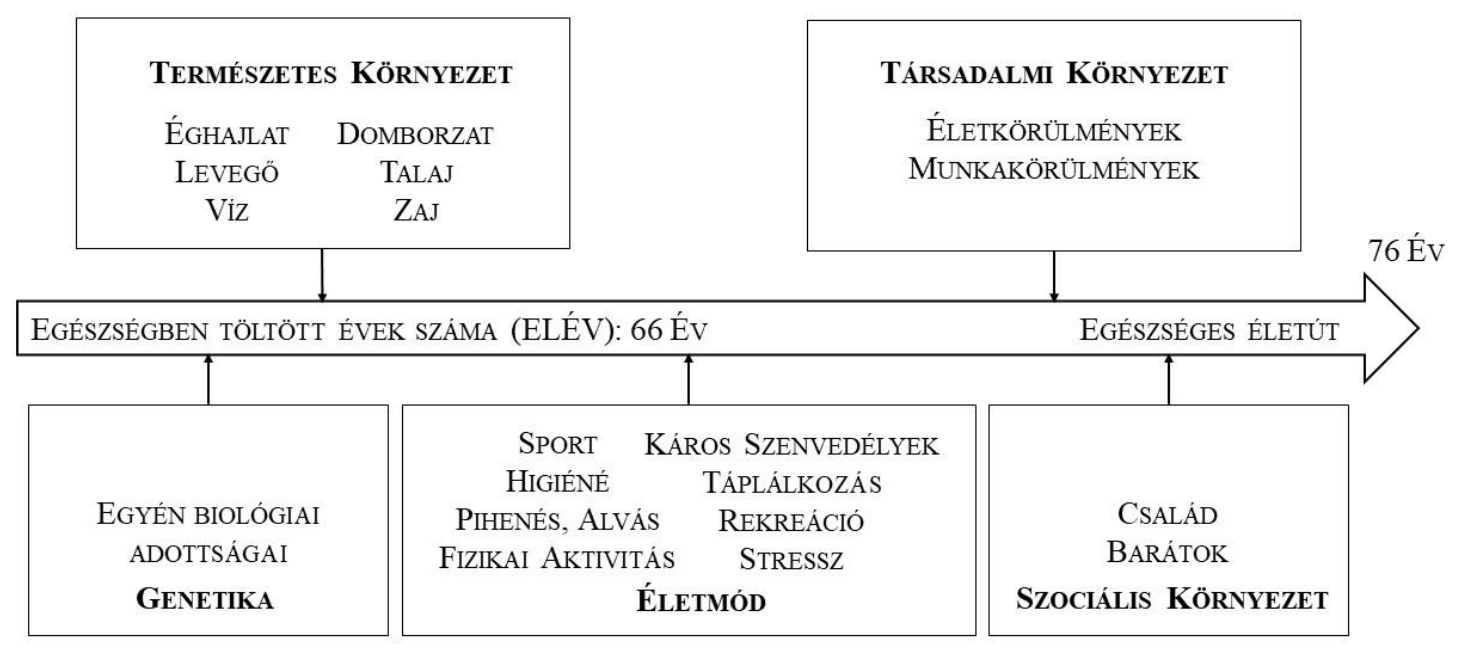

BELSỎ KÖRNYEZETI DIMENZIÓK

2. ábra. Az egészség-modell egyfajta értelmezése az egyénre ható egészség-determinánsok tükrében 
A következőkben szekunder kutatásokkal igazoljuk a modellben ábrázolt tényezők egészségre gyakorolt hatását. A szakirodalmi háttér összeállításánál igyekeztünk minden tényezőre kitérni, de terjedelmi korlát miatt, inkább csak a kutatási probléma jelentősének megvilágítását ígérjük jelen cikkben.

\subsection{A külső hatások egészségre gyakorolt szerepe}

Számos kutatás igazolja, hogy a külső hatások hogyan befolyásolják az egészségünket, melyek között a természeti és a társadalmi környezet is sokszor került a kutatások fókuszába. A természeti környezetet érő szennyezések miatt egyre nagyobb arányban határozza ez meg egészségünket.

\subsubsection{A természeti környezet}

Epidemiológiai vizsgálatok igazolták, hogy a városiasodás, a magas emissziójú területek, a levegőszennyezettség és a nyugati típusú életmód összefüggésben áll a légúti megbetegedések és az allergia nagyobb előfordulásával [25][26][27]. A levegő és légszennyezettség leginkább a légúti megbetegedések gyakoriságát és az abból származó halálozást befolyásolja [28].

Az időjárás nagyban meghatározza a szennyező anyagok levegőben történő felhalmozódásának és eloszlásának feltételeit, azaz jelentősen befolyásolva a levegő minőségének alakulását. A nagyvárosok szennyezett levegője az asztma morbiditásának egyik oka, valamint más légzőszervi megbetegedés prevalenciáját növelve befolyásolja az emberi egészséget [29][30][31][32][33]. Egy Vlagyivosztokban végzett kutatás során igazolták, hogy az asztma morbiditása az általános légszennyezettségtöl függ (18,3\% tartományban). Kimutatták, hogy a legmagasabb életkor-specifikus függőség a levegőben lévő részecskék, szén-monoxid és nitrogén-dioxid tartalmával mutatott öszszefüggést. A klímaváltozás következményeként az éghajlatváltozás, a levegő hőmérsékletének emelkedése is negatívan befolyásolja az asztmás és allergiás betegek állapotát [26][35][36]. Az éghajlat és asztma közti pozitív kapcsolatot is ki tudták mutatni, ahol a magaslati klíma kedvezően befolyásolta az asztmások állapotát [37][38][39][40].

Kínában egy tanulmány arra hívta fel a figyelmet, hogy az iparosodással járó környezetszenynyezés a vizeket is elérte, valamint az alapvető vízellátási és szennyvíztisztító infrastruktúra kritikus hiánya megnövelte a fertőző és parazita betegségek, valamint az ipari vegyszerek, a nehézfémek és az algatoxinok növekvő mennyiségének való kitettség kockázatát [41], Illetve már ez a tanulmány felhívta arra is a figyelmet, hogy a rossz minőségű ivóvíz egészségre ártalmas hatásait több nemzetközi és hazai tanulmány is megerősíti [42][43][44].

\subsection{Társadalmi környezet}

A legkönnyebben behatárolható szociális környezet a munkahely. A munkakörülmények között több károsító tényező is lehet, mint pl. a munkahelyi stressz [45][46][47][48][49], a hosszú időn át tartó munka, a túlóra (ami 61\%-kal növeli a sérülések kialakulását [50]), vagy a tartós egyoldalú terhelés, mint az ülő vagy állómunka [51][52][53][54][55][56]. A munkakörülményeknek az egyén egészségét támogató jellegủnek, vagy akár az egyén állapotához igazítottnak kell lenni [57] annak érdekében, hogy az egészséges munkakörülményhez való jogot biztosítani tudja a munkáltató a munkavállalók számára.

Az életkörülmények vizsgálatával foglalkozó kutatások a lakáskörülményeket és jövedelmet vizsgálják leginkább. A kutatások igazolják, hogy a kedvezőbb szocioökonomiai státusszal rendelkező vizsgált személyek egészségi állapota is kedvezőbb [58][61][59][60][61]. Az anyagi jellegü életkörülményekkel kapcsolatos okok (alacsony jövedelem, anyagi gondok, hátrányos helyzet, a szegénység, a veszélyeztető életkörülmények, munkanélküliség, stb.). önmagukban nem szerepelnek a betegségeket kiváltó elsődleges okokként. azonban legyengítheti az immunrendszert és csökkenti a szervezet ellenálló képességét, így ebböl kifolyólag az egyén nem képes olyan sikeresen felvenni a harcot a különböző károsító hatásokkal, a változatos kórokozókkal. Az életkörülmények így az életminőséget és az egészséget is befolyásolják [62][63][64]. 


\subsection{A belső környezeti tényezők szerepe és jelentősége és egészségdetermináns sze- repe}

Az életmódunk igen nagyban befolyásolja az egészségünket. A modern ember életének egyik jellegzetessége az ülő, mozgás szegény életforma. Bizonyított, hogy a fizikai inaktivitás, vagyis az inaktív életmód növeli számos betegség kialakulásának kockázatát [65], így tehát az inaktív emberek körében gyakrabban fordulnak elö a szív és érrendszeri megbetegedések, az oszteoporózis, a 2-es típusú cukorbetegség, az obezitasz, a stroke, a magas vérnyomás, és a stressz eredetű betegségek [66]. A WHO 2017-es becslései szerint a fizikai inaktivitás 3,2 millió halálesetért felel, amely alapján a negyedik vezető halálozási okként tartják számon a Világon [67]. A mozgásszegény életmód nem csak az egyén számára ártalmas, hanem nemzetgazdasági szinten is komoly terheket ró az államra [68].

Sok kutatás igazolta a rendszeres sportolás egészséges életmódban betöltött szerepét, valamint prevenciós és terápiás hatásait különböző célcsoportok esetében [69][70][71][71].

A rendszeres sportolás tehát az életmódfüggő betegségek és a mentális betegségek prevenciójában is domináns szerepet kap [66][75]Hiba! A hivatkozási forrás nem található.[77][78][79]. A rendszeres sportolás a kardiovaszkuláris megbetegedések kialakulásának kockázatát is csökkenti [80][81][82], mely betegségcsoport nem csak hazánkban, de az egész világon népegészségügyi probléma és igen magas morbiditási és mortalitási adatokat eredményez. Franco és munkatársai Hiba! A hivatkozási forrás nem található. egyben arra is fókuszáltak kutatásukban, hogy a rendszeres fizikai aktivitás növeli a szívbetegek várható élettartamát és életminőségét. Az EUROSTAT adatai alapján a vezető halálozási okok az EU-ban a keringési és a légzőszervi rendszert érintő megbetegedések.

A rekreációs tevékenységek, azaz a szabadidőnk hasznos eltöltését célzó tevékenységeink is hatnak az egészségre, hiszen a céljukat tekintve a pihentető és fejlesztő szerepük által az egyén egészségének és munkaképességének megőrzését szolgálja. Az aktív és passzív szabadidős tevékenységek közül az aktív vagy fizikai rekreációs programok szolgálják leginkább a mozgásszegény életmód hatásainak mérséklését, mely a különböző célcsoportok és lakóhelyeken [83][84] eltérő módon jelenik meg [85]. A rekreációs tevékenységekben megjelenő különböző szabadidős sport [86][87][88] és annak üzése pozitívan korrelál a különböző egészségindikátorokkal [89][90], vagy növeli ez élettel való elégedettséget is [91]. A rekreáció pozitív hatását különböző betegségek kezelésében is felhasználják, mint rekreációs terápiát [92][93][94].

Az aktív tevékenységek mellett a pihenésnek, az alvásnak, illetve a terhelés-pihenés optimális egyensúlyának és arányának is egészség-determináns szerepe van [95][96].

A stressz és a stresszes életmód igazoltan negatívan befolyásolja az emberi egészséget, melyet több tanulmány is megerősít [97][98][100][99][100]. A stressz eredetű betegségek [102][101] megjelenése a rohanó a teljesítmény és időkényszer okozta stresszes életmód következménye. A stresszt elkerülni nem tudjuk, de különböző stressz-oldó technikákat (pl. balneo-, zene-, vagy akár masszázsterápia) alkalmazva csökkenthető a stressz szintje, ami pozitívan korrelál a stressz eredetű betegségek megjelenésével és a szubjektív jó lét növelését eredményezheti [103][89][105][106][107][108][109][110].

Több hazai és nemzetközi kutatás a táplálkozás egészséget igen jelentős mértékben befolyásoló szerepét erősíti meg [111][112][113][114][115][116][117][118][119].

A káros szenvedélyek, mint a dohányzás [121]Hiba! A hivatkozási forrás nem található., alkohol [122][123][124][125]- és drogfogyasztás [126] károsítja egészségünket és növeli a különböző betegségek előfordulásának gyakoriságát, a korai elhalálozást [127] és meghatározó a szerepe az életminőség romlásában is. Több kutatás ismerteti a különböző generációkat érintő káros szenvedélyek fogyasztásának igen magas arányát [128][129].

A kutatások a genetika szerepét is megerősítik az egészségben vagy bizonyos betegségek kialakulásában [130][131][132][133][134][135][136][136], melynek szerepe az orvostudomány fejlödésével csökkent.

Az egyént érintő szociális környezeti hatások közül a család és a barátok szerepe jelentős. A család vagy baráti társaság befolyásolhatja akár pozitív akár negatív irányba az egyén egészségmagatartását, és életmódját [137][138]. Több kutatás megerősíti, hogy az egészségtudatos családokban a szülök a példamutatással, értékközvetítéssel és az egészséget támogató életmódelemek 
(mint pl. sportolás, egészséges táplálkozás, káros szenvedélyektől való mentesség, stb) kialakításával pozitív attitüdöt és egészség-magatartást alakíthatnak ki a gyerekükben [139][140][141][142].

\section{4. Összegzés}

Az egyén egészségét, várható átlagos élettartamát és az egészségben eltöltött életéveinek számát számos úgynevezett belső és külső tényező határozza meg, melyek hatással vannak az egészséges életút meglétére vagy a betegségek kialakulására. Az egészséget befolyásoló tényezők multidimenzionálisak, melyek között kölcsönhatás is van. Az egészség-gazdasági számításokon alapuló modellek nem tudják ezt a sok-tényezős rendszert egy modellben meghatározni, ezért többnyire egy-egy tényezőre (pl. sportolás, fizikai aktivitás, vagy dohányzás, stb.) fókuszálva végeznek egészség-gazdasági számításokat, feltételezve a többi dimenzió konstans voltát. Ám ahogy az egészség-modellünk is mutatja, ezek a tényezők összességében hatnak az egyén életútja során az egészségre, illetve ezek sokszor változnak is ez idő alatt llyen lehet például az életmód-elemben történő változás, az egyén aktivitásának módosulása, amikor, pl. elkezd sportolni vagy épp abbahagyja azt. Az életünk során gyakran változhat a munkahely, munkakör vagy lakókörnyezet a költözéssel. Mivel ezek a dimenziók változnak, a tényezők hatása is változik. Egy modellben ezen hatások együttes számszerüsítése problematikus. A modellünkben ábrázolt egészség-determinánsokat számos kutatás helyezte a fókuszba, melyek igazolták ezek szerepét és jelentőségét. A modell felhívja a figyelmet az egészség holisztikus értelmezésére és segíthet a népegészségügyi programok egészség-determinánsai melletti komplexitás megjelenítésében.

\section{Köszönetnyilvánítás}

A publikáció elkészítését a "GINOP-2.3.2-15-2016-00062 Életminőség fejlesztése Kelet-Magyarországon: Táplálkozás-, teljesítménybiológiai és biotechnológiai experimentális kutatások és eszközfejlesztések a humán megbetegedések megelözésére és kezelésére" projekt támogatta.

\section{Irodalomjegyzék}

[1] Borbély, A., Müller, A., Koncz, I. : A testi-lelki harmónia összefüggései és módszertana, Budapest, Magyarország : Professzorok az Európai Magyarországért Egyesület (2008), p. 211 p.

[2] Brache, A. P. : How organizations work: Taking a holistic approach to enterprise health. John Wiley \& Sons, 2002

[3] Hawks, S. : Spiritual wellness, holistic health, and the practice of health education. American Journal of Health Education, 2004, Vol. 35, No. 1, pp. 11-18, DOI: 10.1080/19325037.2004.10603599

[4] Müller, A., Bácsné, B. É. : Az egészséges életmód és a sport kapcsolata. Létavértes, Magyarország : Létavértes SC '97 Egyesület, 2018, p. 96

[5] Prescott, S. L., Logan, A. C. : Planetary health: from the wellspring of holistic medicine to personal and public health imperative. Explore, 2019, Vol. 15, No. 2, pp. 98-106, DOI: 10.1016/j.explore.2018.09.002

[6] Ruokolainen, L., Lehtimäki, J., Karkman, A., Haahtela, T., von Hertzen, L., \& Fyhrquist, N. : Holistic view on health: two protective layers of biodiversity. In: Annales Zoologici Fennici (Vol. 54, No. 1-4, pp. 39-49). Finnish Zoological and Botanical Publishing Board, 2017

[7] Berg, G. V., Sarvimäki, A. : A holistic-existential approach to health promotion. Scandinavian journal of caring sciences, 2003, Vol. 17, No. 4, pp. 384-391, DOI: 10.1046/j.0283-9318.2003.00240.x

[8] Dooris, M. : Holistic and sustainable health improvement: the contribution of the settings-based approach to health promotion. Perspectives in public health, 2009, Vol. 129, No. 1, pp. 29-36, DOI: $10.1177 / 1757913908098881$

[9] Guidotti, T. L. : Health and sustainability: an introduction, 2015, Oxford University Press

[10] Diener E. : Assessing Subjective Well-Being: Progress and Opportunities. In: Diener E. (eds) Assessing Well-Being. Social Indicators Research Series, 2009, Vol. 39, Springer, Dordrecht. DOI: 10.1007/978-90-481-2354-4 3

[11] Diener, E., Diener, M., Diener, C. Factors predicting the subjective well-being of nations. In Culture and well-being, 2009, Springer, Dordrecht, pp. 43-70

[12] Diener, E., Ryan, K. : Subjective well-being: A general overview. South African journal of psychology, 2009, Vol. 39, No. 4, pp. 391-406, DOI: $10.1177 / 008124630903900402$ 
[13] Lengyel, A., Kovács, S., Müller, A., Lóránt, D., Szőke, Sz., Bácsné B. É. : Sustainability and Subjective Well-Being: How Students Weigh Dimensions, Sustainability, 2019, Vol. 11, No. 23, 6627, DOI: $10.3390 /$ su11236627

[14] Ryff, C. D. : Psychological well-being in adult life, Current directions in psychological science, 1995, Vol. 4, No. 4, pp. 99-104, DOI: $10.1111 / 1467-8721 . e p 10772395$

[15] Johnston, R. J., Gregory, D., Pratt, G., Watts, M. : The Dictionary of Human Geography. Blackwell Publishers Ltd., Oxford, 2000, p. 235

[16] Vitrai, J., Varsányi, P., Bakacs, M. : Új lehetőségek a magyarországi egészségveszteségek becslésére, Lege Artis Medicinae, 2015, Vol. 25, pp. 283-290

[17] Uzzoli, A., Szilágyi, D. : Life expectancy and its regional inequalities in Hungary, Geographica Pannonica, 2009, Vol. 13, No. 4., pp. 127-136, DOI: 10.5937/GeoPan0904127U

[18] The World Bank : Life expectancy at birth, total (years) - Hungary, https://data.worldbank.org/indicator/SP.DYN.LE00.IN?locations=HU

[19] WHO : Healthy life expectancy (HALE) at birth (years), 2014, http://data.un.org/Data.aspx?d=WHO\&f=MEASURE CODE\%3AWHOSIS 000002

[20] Orosz, É., Káló, Z., Nagy, B. : Egészség-gazdaságtan, 2011, 17.p. http://www.tankonyvtar.hu/hu/tartalom/tamop425/0041 egeszseggazdtan/01 het Egeszseg-gazdtan vegleges 4 4.html

[21] Ács, P., Stocker, M., Kovács, A., Hoffbauer, M., Szabó, P., Paár, D. : A magyarországi fizikai inaktivitási terhek alakulásának összehasonlító elemzése, 2009-2017, Közgazdasági Szemle, 2020, Vol. 67, No. 7-8, pp. 809-830

[22] Anis, A. H., Zhang, W., Bansback, N., Guh, D. P., Amarsi, Z., Birmingham, C. L. : Obesity and overweight in Canada: an updated cost-of-illness study, Obesity reviews, 2010, Vol. 11, No. 1, pp. 31-40, DOI: 10.1111/j.1467789X.2009.00579.x

[23] Voigt, J., Sasha, J. M., Taylor, A., Krucoff, M., Reynolds, M. R., Michael, G. C. : A reevaluation of the costs of heart failure and its implications for allocation of health resources in the United States, Clin Cardiol, 2014, Vol. 37, No. 5, pp. 312-21, DOI: $\underline{10.1002 / \mathrm{clc} .22260}$

[24] Herczeg, B., Gerencsér, Zs., Rózsa, P. : Az aszpirin (acetilszalicilsav) egészség-gazdaságtani elemzése atheroszklerotikus betegségek primer prevenciójában. IME: Informatika és Menedzsment az Egészségügyben, 2008, Vol. 7, No. 8, pp. 46-50

[25] D’Amato, G., Vitale, C., De Martino, A., Viegi, G., Lanza, M., Molino, A., Sanduzzi, A., Vatrella, A., Annesi-Maesano, I., D'Amato, M. : Effects on asthma and respiratory allergy of Climate change and air pollution, Multidiscip Respir Med, 2015, Vol. 10, No. 39, DOI: 10.1186/s40248-015-0036-X

[26] Ferrari, U., Exner, T., Wanka, E. R., Bergemann, C., Meyer-Arnek, J., Hildenbrand, B., Tufman, A., Heumann, C., Huber, R. M., Bittner, M., Fischer, R. : Influence of air pressure, humidity, solar radiation, temperature, and wind speed on ambulatory visits due to chronic obstructive pulmonary disease in Bavaria, Germany, Int J Biometeorol, 2012, Vol. 56, No. 1, pp. 137-143 DOI: 10.1007/s00484-011-0405-x

[27] Guarnieri, M., Balmes, J. R. : Outdoor air pollution and asthma, Lancet, 2014, Vol. 383, No. 9928, pp. 1581-1592, DOI: $10.1016 /$ S0140-6736(14)60617-6

[28] Veremchuk, L. V., Yankova, V. I., Vitkina, T. I., Nazarenko, A. V., Golokhvast, K. S. : Urban air pollution, climate and its impact on asthma morbidity, Asian Pacific Journal of Tropical Biomedicine, 2016, Vol. 6, No. 1, pp. 76-79, DOI: $10.1016 /$ /.apjtb.2015.10.001

[29] Harpham, T. : Urban health in the Gambia: a review, Health \& Place, 1996, Vol. 2, No. 1, pp. 45-9, DOI: $\underline{10.1016 / 1353-8292(95) 00041-0}$

[30] Jacquemin, B., Kauffmann, F., Pin, I., Le Moual, N., Bousquet, J., Gormand, F., Just, J., Nadif, R., Pison, C., Vervloet, D., Künzli, N., Siroux, V. : Air pollution and asthma control in the Epidemiological study on the Genetics and Environment of Asthma, J Epidemiol Community Health, 2012, Vol. 66, No. 9, pp. 796-802, DOI: 10.1136/jech.2010.130229

[31] Rage, E., Siroux, V., Künzli, N., Pin, I., \& Kauffmann, F. : Air pollution and asthma severity in adults, Occupational and environmental medicine, 2009, Vol. 66, No. 3, pp. 182-188, DOI: 10.1136/oem.2007.038349

[32] Su, M.R., Brian, D.F., Yang, Z.F. : Urban ecosystem health assessment: a review. Sci Total Environ, 2010 , Vol. 408, No. 12, pp. 2425-2434, DOI: 10.1016/j.scitotenv.2010.03.009

[33] Tian, G. E., Lu, Y. H., Gu, F., Liu, N. N., Chen, X. Q. : Methodology of urban ecosystem healthassessment, J Chin Urban Forestry, 2009, Vol. 7, No. 1, pp. 57-60.

[34] Ferrari, U., Exner, T., Wanka, E. R., Bergemann, C., Meyer-Arnek, J., Hildenbrand, B., Tufman, A., Heumann, C., Huber, R. M., Bittner, M., Fischer, R. : Influence of air pressure, humidity, solar radiation, temperature, and wind speed on ambulatory visits due to chronic obstructive pulmonary disease in Bavaria, Germany, Int J Biometeorol, 2012, Vol. 56, No. 1, pp. 137-143 DOI: $\underline{10.1007 / \mathrm{s} 00484-011-0405-\mathrm{x}}$ 
[35] Götschke, J., Mertsch, P., Bischof, M., Kneidinger, N., Matthes, S., Renner, E. D., Schultz, K., Traidl-Hoffmann, C., Duchna, H. W., Behr, J., Schmude, J., Huber, R. M., Milger, K. : Perception of climate change in patients with chronic lung disease, PLoS ONE, 2017, Vol. 12, No. 10, DOI: 10.1371/journal.pone.0186632

[36] Zanobetti, A., O'Neill, M. S., Gronlund, C. J., Schwartz, J. D. : Summer temperature variability and long-term survival among elderly people with chronic disease, Proc Natl Acad Sci USA, 2012, Vol. 109, No. 17, 6608-6613, DOI: 10.1073/pnas.1113070109

[37] Huismans, H. K., Douma, W. R., Kerstjens, H. A., Renkema, T. E. : Asthma in patients climbing to high and extreme altitudes in the Tibetan Everest region, J. Asthma, 2010 No. 47, pp. 614-619

[38] Müller, A., Balatoni, I., Csernoch, L., Bács, Z., Bíró, M., Bendíková, E., Pesti, A. : Quality of life of asthmatic patients after complex rehabilitation treatment, Orvosi hetilap, 2018a, Vol. 159, No. 27, pp. 1103-1112.

[39] Müller, A., Ráthonyi, G., Bíró, M., Ráthonyi-Ódor, K., Bács, Z., Ács, P., Hegyi, G., Bába, É. B. : The effect of complex climate therapy on rehabilitation results of elderly asthmatic and chronic obstructive airways disease (COPD) patients, European Journal Of Integrative Medicine, 2018b, 20, pp. 106-114, DOI: 10.1016/j.eujim.2018.04.007

[40] Rijssenbeek-Nouwens, L. H., Fieten, K. B., Bron, A.O., Hashimoto, S., Bel, E. H., Weersink, E. J. : High-altitude treatment in atopic and nonatopic patients with severe asthma, Eur. Respir J., 2012, No. 40, pp. 1374-1380, DOI: $\underline{10.1183 / 09031936.00195211}$

[41] Wu, C., Maurer, C., Wang, Y., Xue, S., Davis, D. L. : Water pollution and human health in China. Environmental Health Perspectives, 1999, Vol. 107, No. 4., pp. 251-256, DOI: 10.1289/ehp.99107251

[42] Azizullah, A., Khattak, M. N. K., Richter, P., Häder, D. P. : Water pollution in Pakistan and its impact on public health-a review. Environment international, 2011, Vol. 37, No. 2, pp. 479-497, DOI: 10.1016/j.envint.2010.10.007

[43] Halder, J. N., Islam, M. N. : Water pollution and its impact on the human health, Journal of environment and human, 2015, Vol. 2, No. 1, pp. 36-46, DOI: 10.15764/EH.2015.01005

[44] Schwarzenbach, R. P., Egli, T., Hofstetter, T. B., Von Gunten, U., Wehrli, B. : Global water pollution and human health, Annual review of environment and resources, 2010, No. 35, pp. 109-136.

[45] Griffin, J. M., Greiner, B. A., Stansfeld, S. A., Marmot, M. : The effect of self-reported and observed job conditions on depression and anxiety symptoms: a comparison of theoretical models, J Occup Health Psychol, 2007, Vol. 12, No. 4, pp. 334-349, DOI: 10.1037/1076-8998.12.4.334

[46] Kerr, R., McHugh, M., McCrory, M. : HSE management standards and stress-related work outcomes, Occup Med (Lond), 2009, Vol. 59, No. 12, pp. 574-579, DOI: 10.1093/occmed/kqp146

[47] Molnár, E. : Kommunikáció, meggyőzés, reklám, Szolnok, Magyarország : Alumni, 2017b

[48] Netterstrom, B., Conrad, N., Bech, P., Fink, P., Olsen, O., Rugulies, R., Stansfeld, S. : The relation between workrelated psychosocial factors and the development of depression, Epidemiol Rev, 2008 Vol. 30, No. 36, pp. 118132, DOI: $10.1093 /$ epirev/mxn004

[49] O'Neill, E., McNamee, R.. Agius, R., Gittins, M., Hussey, L., Turner, S. : The validity and reliability of diagnoses of work-related mental ill-health, Occup Environ Med, 2008. Vol. 65, No. 11, pp. 726-731, DOI: 10.1136/oem.2008.039008

[50] Dembe, A. E., Erickson, J. B., Delbos, R. G., Banks, S. M. : The impact of overtime and long work hours on occupational injuries and illnesses: new evidence from the United States. Occupational and environmental medicine, 2005, Vol. 62, No. 9, pp. 588-597, DOI: 10.1136/oem.2004.016667

[51] Agarwal, S., Steinmaus, C., Harris-Adamson, C. : Sit-stand workstations and impact on low back discomfort: a systematic review and meta-analysis. Ergonomics, 2018, Vol. 61, No. 4, pp. 538-552, DOI: $\underline{10.1080 / 00140139.2017 .1402960}$

[52] Alkhajah, T. A., M. M. Reeves, E. G. Eakin, E. A. Winkler, N. Owen, G. N. Healy. : Sit-stand Workstations: A Pilot Intervention to Reduce Office Sitting Time, American Journal of Preventive Medicine, 2012, Vol. 43, No. 3, pp. 298303, DOI: $10.1016 /$ /.amepre.2012.05.027

[53] Andersen, J. H., J. P. Haahr, Frost, P. : Risk Factors for More Severe Regional Musculoskeletal Symptoms: A Twoyear Prospective Study of a General Working Population, Arthritis \& Rheumatism, 2007, Vol. 56, No. 4, pp. 13551364, DOI: $10.1002 /(I S S N) 1529-0131$

[54] Davis, K. G., Kotowski, S. E. : Postural Variability: An Effective Way to Reduce Musculoskeletal Discomfort in Office Work, Human Factors: The Journal of the Human Factors and Ergonomics Society, 2014, Vol. 56, No. 7, pp. 12491261, DOI: $10.1177 / 0018720814528003$

[55] Davis, K. G., Kotowski, S. E., Sharma, B., Herrmann, D., Krishnan, A. P. : Combating the Effects of Sedentary Work: Postural Variability Reduces Musculoskeletal Discomfort, Proceedings of the Human Factors and Ergonomics Society Annual Meeting, 2009, Vol. 53, No. 14, pp. 884-886, DOI: 10.1177/154193120905301406 
[56] Ebara, T., T. Kubo, T. Inoue, G., Murasaki, I., Takeyama, H., Sato, T., Suzumura, H., Itani T. : Effects of Adjustable Sit-stand VDT Workstations on Workers' Musculoskeletal Discomfort, Alertness and Performance, Industrial Health, 2008, Vol. 46, No. 5, pp. 497-505, DOI: $\underline{10.2486 / \text { indhealth.46.497 }}$

[57] Balázs-Földi, E., Dajnoki, K. : Sajátosságok a fogyatékos és megváltozott munkaképességű munkavállalók foglalkoztatásában. Gradus, 2016, Vol. 3, No. 1, pp. 313-318.

[58] Adler, N. E., Ostrove, J. M. : Socioeconomic status and health: what we know and what we don't. Annals of the New York academy of Sciences, 1999, Vol. 896, No. 1, pp. 3-15, DOI: 10.1111/j.1749-6632.1999.tb08101.x

[59] Oakes, J. M., Rossi, P. H. : The measurement of SES in health research: current practice and steps toward a new approach. Social science \& medicine, 2003, Vol. 56, No. 4, pp. 769-784, DOI: 10.1016/S0277-9536(02)00073-4

[60] Shavers, V. L. : Measurement of socioeconomic status in health disparities research. Journal of the national medical association, 2007, Vol. 99, No. 9, pp. 1013-1023

[61] Uzzoli, A. : A budapesti 14-19 év közötti korosztály életkörülményeinek vizsgálata esettanulmányok alapján, Tér és Társadalom, 2000, Vol. 14, No. 2-3, pp. 229-237, DOI: 10.17649/TET.14.2-3.590

[62] Freudenberg, N., Galea, S., Vlahov, D. : Beyond urban penalty and urban sprawl: back to living conditions as the focus of urban health. Journal of community health, 2005, Vol. 30, No. 1, pp. 1-11, DOI: 10.1007/s10900-004-6091$\underline{4}$

[63] Huttmann, S. E., Windisch, W., Storre, J. H. : Invasive home mechanical ventilation: living conditions and healthrelated quality of life. Respiration, 2015, Vol. 89, No. 4, pp. 312-321, DOI: $10.1159 / 000375169$

[64] Lundberg, O. : Childhood living conditions, health status, and social mobility: a contribution to the health selection debate. European Sociological Review, 1991, Vol. 7, No. 2, pp. 149-162, DOI: 10.1093/oxfordjournals.esr.a036593

[65] Murtaza, S. A., Molnár, E., Szakács, A. : Digital Heroin - The Impact of Digital Gadgets on Developing Minds An Empirical Study on Growing Children of Lahore, Controller Info, 2021, Vol. 9, No. 1, pp. 55-58.

[66] Apor, P. : Testedzéssel a megbetegedések ellen, Magyar Tudomány, 2012, Vol. 173, No. 12, pp. 1470-1477

[67] Pratt, M., Norris, J., Lobelo, F., Roux, L., Wang, G. : The cost of physical inactivity: moving into the 21st century, British Journal of Sports Medicine, 2014, Vol. 48, No. 3. pp. 171-173, DOI: 10.1136/bjsports-2012-091810

[68] Herpainé, L. J., Boda, E., Varga, A., Váczi, P. : Három generáció tevékenység- és értékrendszererének jellemzői a fizikai aktivitás tükrében. Magyar Sporttudományi Szemle, 2018, Vol. 19, No. 3, p. 47

[69] Brown, W.J., McLaughlin, D., Leung, J., McCaul, K. A., Flicker, L., Almeida, O. P., Hankey, G. J., Lopez, D., Dobzon A. J. : Physical activity and all-cause mortality in older women and men, Br J Sports Med, 2012, Vol. 46, No. 9 pp. 664-668, DOI: 10.1136/bjsports-2011-090529

[70] Cardoso, C., Freitas, M., Rombaldi, A. : School-based Interventions to Promote a Healthy Life Style among Elementary School Students. Revista Brasileira de Ciências Sociais, 2016, Vol. 20, No. 3, pp. 247-253

[71] Hillsdon, M. M., Brunner, E. J., Guralnik, J. M., Marmot, M. G. : Prospective study of physical activity and physical function in early old age. Am J Prev Med, 2005, Vol. 28, No. 3, pp. 245-250, DOI: 10.1016/j.amepre.2004.12.008

[72] Lacza, G., Radák, Z. : Is physical activity an elixir?. Elixír-e a testedzés? Orvosi hetilap, 2013, Vol. 154, No. 20, pp. 764-768

[73] Apor, P. : Testedzéssel a megbetegedések ellen, Magyar Tudomány, 2012, Vol. 173, No. 12, pp. 1470-1477

[74] mentary School Students. Revista Brasileira de Ciências Sociais, 2016, Vol. 20, No. 3, pp. 247-253

[75] Carless, D., Douglas, K. : Narrative, identity and mental health: How men with serious mental illness re-story their lives through sport and exercise, Psychology of sport and exercise, 2008b, Vol. 9, No. 5, pp. 576-594, DOI: 10.1016/i.psychsport.2007.08.002

[76] Carless, D., Douglas, K. : The Role of Sport and Exercise in Recovery from Serious Mental Illness: Two Case Studies, International journal of men's health, 2008a, Vol. 7, No. 2, pp. 137-156, DOI: 10.3149/jmh.0702.137

[77] Daumit, G. L., Goldberg, R. W., Anthony, C., Dickerson, F., Brown, C. H., Kreyenbuhl, J., Wohlheiter, K., Dixon, L. B. : Physical activity patterns in adults with severe mental illness, The Journal of nervous and mental disease, 2005, Vol. 193, No. 10, pp. 641-646, DOI: 10.1097/01.nmd.0000180737.85895.60

[78] Lukács, A. : A táplálkozás és a sport szerepe időskorban a lelki és a fizikai egészség megőrzése érdekében. Magyar Gerontológia, 2017, Vol. 9, No. 33, pp. 23-33, DOI: 10.47225/MG/9/33/8126

[79] Pavlik, G. : A rendszeres fizikai aktivitás szerepe betegségek megelőzésében, az egészség megőrzésében, Egészségtudomány, 2015, Vol. 59, No. 2, pp. 11-26.

[80] Carnethon, M. R. : Physical activity and cardiovascular disease: how much is enough?. American journal of lifestyle medicine, 2009, Vol. 3 No. 1, pp. 44S-49S, DOI: $\underline{10.1177 / 1559827609332737}$ 
[81] Hu, G., Jousilahti, P., Barengo, N. C., Qiao, Q., Lakka, T. A., Tuomilehto, J. : Physical activity, cardiovascular risk factors, and mortality among Finnish adults with diabetes, Diabetes care, 2005, Vol. 28, No. 4, pp. 799-805, DOI: $\underline{10.2337 / \text { diacare.28.4.799 }}$

[82] Wang, G., Pratt, M., Macera, C. A., Zheng, Z. J., Heath, G. : Physical activity, cardiovascular disease, and medical expenditures in US adults. Annals of Behavioral Medicine, 2004, Vol. 28, No. 2, pp. 88-94, DOI: $\underline{10.1207 / \mathrm{s} 15324796 \mathrm{abm} 28023}$

[83] Horkay, B., Lenténé, P. A., Biró M. : The supply elements and the recreational possibilities in the city and in the countryside. In: Šimonek, J., Dobay, B. : Mozgásban a sporttudomány: válogatott tanulmányok a konferenciáról. Komárno, Szlovákia : Univerzita J. Selyeho, 2018a, pp. 330-339

[84] Horkay, B., Lenténé, P. A., Bíró, M. : A város és vidék kínálati elemeinek és szabadidős lehetőségeinek összehasonlítása egy vizsgálat tükrében. In: Balogh, L. : Fókuszban az egészség. Debrecen, Magyarország: Debreceni Egyetem Sporttudományi Koordinációs Intézet, 2018b, pp. 94-105.

[85] Yiğiter, K., Sarı, İ., Ulusoy, Y. Ö., Soyer, F. : Examining the effect of recreational activities on University Students'self-Esteem, Sport Scientific and Practical Aspects, 2011, Vol. 8, No. 2, pp. 15-19.

[86] Honfi, L., Szalay, G., Váczi, P. : A sport beépülése a mindennapokba. Acta Academiae Paedagogicae Agriensis Nova Series: Sectio Sport, 2009, Vol. 36, pp. 51-63.

[87] Váczi, P. : A rekreáció elmélete és módszertana 1.: labdás és golyós sportágak. Eger, Magyarország : Líceum Kiadó, 2015b, 31 p.

[88] Váczi, P. : Basketball pp. In: Bíró, M. (szerk.) Ball games : handball, football, volleyball, basketball. Eger, Magyarország : EKC Líceum Press, 2015a, pp. 93-124.

[89] Biró, M., Bendíková, E., Michal, M., Tütünkov-Hrisztov, J., Lenténé, P. A. : A masszázs, mint szolgáltatási kategória megjelenése az Észak-alföldi szállodák kínálatában, Különleges Bánásmód, 2019, Vol. 5, No. 4, pp. 21-32, DOI: $\underline{10.18458 / K B .2019 .4 .21}$

[90] Lenténé, P. A., Biró, M., Dobay, B., Pucsok, J. M. : A szabadidő sportolás kínálati elemeinek, és szolgáltatásainak vizsgálata Magyarország Észak-alföldi régiójának szállodáiban. Selye E-Studies. 2018, Vol. 9, No. 1, pp. 13-21.

[91] McGuinn, K. K., Mosher-Ashley, P. M. : Participation in recreational activities and its effect on perception of life satisfaction in residential settings. Activities, Adaptation \& Aging, 2001, Vol. 25, No. 1, pp. 77-86, DOI: 10.1300/J016v25n01 06

[92] Austin, D. R., Crawford, M. E., McCormick, B. P. : Recreational therapy: An introduction. M. Van Puymbroeck (Ed.). Sagamore Publishing, LLC., 2020, p. 332

[93] Felson, D. T., Niu, J., Clancy, M., Sack, B., Aliabadi, P., Zhang, Y. : Effect of recreational physical activities on the development of knee osteoarthritis in older adults of different weights: the Framingham Study. Arthritis Care \& Research: Official Journal of the American College of Rheumatology, 2007, Vol. 57, No. 1, pp. 6-12, DOI: 10.1002/art.22464

[94] Porter, H. R., Hawkins, B. L., Kemeny, B. : Recreational Therapy Competencies, Part I: The ATRA Delphi Study, Therapeutic Recreation Journal, 2020, Vol. 54, No. 4, pp. 391-401, DOI: 10.18666/TRJ-2020-V54-I4-10237

[95] Lee, S. Y., Hsu, H. C. : Stress and health-related well-being among mothers with a low birth weight infant: The role of sleep. Social science \& medicine, 2012, Vol. 74, No. 7, pp. 958-965, DOI: 10.1016/j.socscimed.2011.12.030

[96] Williams, S. J. : Sleep and health: sociological reflections on the dormant society. Health, 2002, Vol. 6, No. 2, pp. 173-200, DOI: $10.1177 / 136345930200600203$

[97] Molnár, E. : Szupervízió a szociális munkában, Szociálpedagógia: Nemzetközi Szaklektorált Folyóirat, 2017a, Vol. 5, No. 1-2, pp. 99-106.

[98] Schneiderman, N., Ironson, G., Siegel, S. D. : Stress and health: psychological, behavioral, and biological determinants, Annual review of clinical psychology, 2005, No. 1, pp. 607-628, DOI: 10.1146/annurev.clinpsy.1.102803.144141

[99] Shirom, A. : The effects of work stress on health, The handbook of work and health psychology, 2003, No. 2, pp. 63-82, DOI: $10.1002 / 0470013400 . c h 4$

[100]Zautra, A. J. : Emotions, stress, and health, Oxford University Press, 2003, p. 328

[101] Nieuwenhuijsen, K., Bruinvels, D., Frings-Dresen, M. : Psychosocial work environment and stress-related disorders, a systematic review. Occupational medicine, 2010, Vol. 60, No. 4, pp. 277-286, DOI: 10.1093/occmed/kqq081

[102] Pacak, K., Palkovits, M. : Stressor specificity of central neuroendocrine responses: implications for stress-related disorders, Endocrine reviews, 2001, Vol. 22, No. 4, pp. 502-548, DOI: $\underline{10.1210 / \text { edrv.22.4.0436 }}$

[103] Abriel, S., Albuquerque, E., Tarelho, A., Duarte, M. : When psychiatric symptoms precede the diagnosis of lung cancer; a case report. Psychotherapy \& Psychosomatics, 2013, Vol. 82, No. 1, pp. 1. DOI: $10.1159 / 000354142$ 
[104]Biró, M., Bendíková, E., Michal, M., Tütünkov-Hrisztov, J., Lenténé, P. A. : A masszázs, mint szolgáltatási kategória megjelenése az Észak-alföldi szállodák kínálatában, Különleges Bánásmód, 2019, Vol. 5, No. 4, pp. 21-32, DOI: $\underline{10.18458 / \text { KB.2019.4.21 }}$

[105]Bodolai, M., Lívják, E., Boda, E., Bíró, M. : A jóga hatása a szervezetre, szerepe a stresszkezelésben, Acta Academiae Paedagogicae Agriensis Nova Series: Sectio Sport, 2016, Vol. 43, pp. 51-67.

[106] Grocke, D., Bloch, S., Castle, D. : The effect of group music therapy on quality of life for participants living with a severe and enduring mental illness. Journal of music therapy, 2009, Vol. 46, No. 2, pp. 90-104, DOI: $10.1093 / \mathrm{jmt} / 46.2 .90$

[107] Mahipalan, M., Sheena, S. : Workplace spirituality, psychological well-being and mediating role of subjective stress: A case of secondary school teachers in India, International Journal of Ethics and Systems, 2019, Vol. 35, No. 4, pp.725-739, DOI: 10.1108/IJOES-10-2018-0144

[108] Matzer, F., Nagele, E., Bahadori, B., Dam, K., Fazekas, C. : Stress-relieving effects of short-term balneotherapy-a randomized controlled pilot study in healthy adults, Complementary Medicine Research, 2014, Vol. 21, No. 2, pp. 105-110, DOI: $\underline{10.1159 / 000360966}$

[109] Molnár, E. : A kommunikáció előmozdítója és hátráltatója: empátia és szorongás. Kommunikáció Média Gazdaság, 2007, Vol. 5, No. 3, pp. 85-93.

[110] Rapaport, M. H., Schettler, P. J., Larson, E. R., Carroll, D., Sharenko, M., Nettles, J., Kinkead, B. : Massage therapy for psychiatric disorders, Focus, 2018, Vol. 16, No. 1, pp. 24-31, DOI: 10.1176/appi.focus.20170043

[111]Erdei, G., Kovács, V. A., Bakacs, M., Martos, É. : Országos Táplálkozás és Tápláltsági Állapot Vizsgálat 2014. I. A magyar felnőtt lakosság tápláltsági állapota. Orvosi Hetilap, 2017, Vol. 158, No. 14, pp. 533-540, DOI: $\underline{10.1556 / 650.2017 .30700}$

[112] Martínez-González, M. Á., Hershey, M. S., Zazpe, I., Trichopoulou, A. : Transferability of the Mediterranean diet to non-Mediterranean countries. What is and what is not the Mediterranean diet, Nutrients, 2017, Vol. 9, No. 11, pp. 1226, DOI: $10.3390 /$ nu9111226

[113] Papas, A. M. : Antioxidant status, diet, nutrition, and health, CRC press, 2019, p. 672

[114] Razavi, A. C., Sapin, A., Monlezun, D. J., McCormack, I. G., Latoff, A., Pedroza, K., McCullough, C., Sarris, L., Schlag, E., Dyer, A., Harlan, T. S. : Effect of culinary education curriculum on Mediterranean diet adherence and food cost savings in families: A randomised controlled trial. Public Health Nutr, 2020, 1-7, DOI: $10.1017 / \mathrm{S} 1368980020002256$

[115] Shen, J., Wilmot, K. A., Ghasemzadeh, N., Molloy, D. L., Burkman, G., Mekonnen, G., Gongora, M. C., Quyyumi, A. A., Sperling, L. S. : Mediterranean dietary patterns and cardiovascular health, Annual review of nutrition, 2015, Vol. 35, pp. 425- 449, DOI: 10.1146/annurev-nutr-011215-025104

[116] Slawson, D. L., Fitzgerald, N., Morgan, K. T. : Position of the Academy of Nutrition and Dietetics: the role of nutrition in health promotion and chronic disease prevention. Journal of the Academy of Nutrition and Dietetics, 2013, Vol. 113, No. 7, pp. 972-979, DOI: 10.1016/j.jand.2013.05.005

[117] Szakály, Z. : Egészségmagatartás és funkcionális élelmiszerek: hogyan vélekednek a hazai fogyasztók?, Élelmiszer, táplálkozás és marketing, 2009, Vol. 6, No. 1-2, pp. 9-18

[118] Szakály, Z. : Trendek és tendenciák a funkcionális élelmiszerek piacán: mit vár el a hazai fogyasztó?, Élelmiszer, táplálkozás és marketing, 2008, Vol. 5, No. 2-3, 3-11

[119]Zhu, L. Q., Zhang, L., Zhang, J., Chang, G. L., Liu, G., Yu, D. D., Yu, X. M., Zhao, M. S., Ye, B. : Evodiamine inhibits high-fat diet-induced colitis-associated cancer in mice through regulating the gut microbiota, Journal of Integrative Medicine, 2020, Vol. 19, No. 1, pp. 56-65, DOI: 10.1016/j.joim.2020.11.001

[120] Johnston, R. J., Gregory, D., Pratt, G., Watts, M. : The Dictionary of Human Geography. Blackwell Publishers Ltd., Oxford, 2000, p. 235

[121] Kanis, J. A., Johnell, O., Odén, A., Johansson, H., De Laet, C., Eisman, J. A., Fujiwara, S., Kroger, H., McCloskey, E. V., Mellstrom, V., Melton, L. J., Pols, H., Reeve, J., Silman, A., Tenenhouse, A. : Smoking and fracture risk: a meta-analysis. Osteoporosis international, 2005, Vol. 16, No. 2, pp. 155-162, DOI: $10.1007 / \mathrm{s} 00198-004-1640-3$

[122] Bagnardi, V., Rota, M., Botteri, E., Tramacere, I., Islami, F., Fedirko, V., Scotti, L., Jenab, M., Turati, F., Pasquali, E., Pelucchi, C., Bellocco, R., Negri, E., Corrao, G., Rehm, J., Boffetta, P.,La Vecchia, C. : Light alcohol drinking and cancer: a meta-analysis. Annals of oncology, 2013, Vol. 24, No. 2, 301-308, DOI: 10.1093/annonc/mds337

[123] Corrao, G., Bagnardi, V., Zambon, A., La Vecchia, C. : A meta-analysis of alcohol consumption and the risk of 15 diseases. Preventive medicine, 2004, Vol. 38, No. 5, pp. 613-619, DOI: 10.1016/j.ypmed.2003.11.027

[124] Holman, C. D. A. J., English, D. R., Milne, E., Winter, M. G. : Meta-analysis of alcohol and all-cause mortality: a validation of NHMRC recommendations. Medical Journal of Australia, 1996, Vol. 164, No. 3, pp. 141-145, DOI: 10.5694/j.1326-5377.1996.tb122011.x 
[125] Östergren, O., Martikainen, P., Lundberg, O. : The contribution of alcohol consumption and smoking to educational inequalities in life expectancy among Swedish men and women during 1991-2008. International journal of public health, 2018, Vol. 63, No. 1, pp. 41-48, DOI: 10.1007/s00038-017-1029-7

[126] Chandler, R. K., Fletcher, B. W., Volkow, N. D. : Treating drug abuse and addiction in the criminal justice system: improving public health and safety. Jama, 2009, Vol. 301, No. 2, pp. 183-190, DOI: 10.1001/jama.2008.976

[127] Leon, D. A., Shkolnikov, V. M., McKee, M. : Alcohol and Russian mortality: a continuing crisis. Addiction, 2009, Vol. 104, No. 10, pp. 1630-1636, DOI: 10.1111/j.1360-0443.2009.02655.X

[128] Láng, P. F., Bíró, M., Kopkáné, P. J. : A leendő testkulturális szakember dohányzási szokásainak, dohányzással kapcsolatos nézeteinek vizsgálata, Acta Academiae Paedagogicae Agriensis Nova Series: Sectio Sport, 2012, Vol. 39 pp. 13-30

[129] Wells, K., Klap, R., Koike, A., Sherbourne, C. : Ethnic disparities in unmet need for alcoholism, drug abuse, and mental health care. American Journal of Psychiatry, 2001, Vol. 158, No. 12, pp. 2027-2032, DOI: 10.1176/appi.ajp.158.12.2027

[130] Abbott, P. W., Gumusoglu, S. B., Bittle, J., Beversdorf, D. Q., Stevens, H. E. : Prenatal stress and genetic risk: How prenatal stress interacts with genetics to alter risk for psychiatric illness. Psychoneuroendocrinology, 2018, Vol. 90, pp. 9-21, DOI: 10.1016/j.psyneuen.2018.01.019

[131] Barroso, I. : Genetics of type 2 diabetes. Diabetic Medicine, 2005, Vol. 22, No. 5, pp. 517-535, DOI: 10.1111/i.1464$\underline{5491.2005 .01550 . x}$

[132] Condit, C. M. : Public understandings of genetics and health. Clinical genetics, 2010, Vol. 77, No. 1, pp. 1-9, DOI: 10.1111/j.1399-0004.2009.01316.x

[133] Prasad, R. B., Groop, L. : Genetics of type 2 diabetes_pitfalls and possibilities, Genes, 2015, Vol. 6, No. 1, pp. 87123, DOI: $10.3390 /$ genes6010087

[134] Sankar, P., Cho, M. K., Condit, C. M., Hunt, L. M., Koenig, B., Marshall, P., Lee, S. S. J., Spicer, P. : Genetic research and health disparities, Jama, 2004, Vol. 291, No. 24, pp. 2985-2989, DOI: 10.1001/jama.291.24.2985

[135] Short, S. E., Yang, Y. C., Jenkins, T. M. : Sex, gender, genetics, and health, American journal of public health, 2013, Vol. 103, No. S1, pp. S93-S101, DOI: 10.2105/AJPH.2013.301229

[136] Stewart, T. L., Ralston, S. H. : Role of genetic factors in the pathogenesis of osteoporosis. Journal of Endocrinology, 2000, Vol. 166 No. 2, pp. 235-246, DOI: $10.1677 /$ joe. 0.1660235

[137] Nagy, B. E., Kovács, K. E. : Egészség-magatartással kapcsolatos attitűdök vizsgálata középiskolás és egyetemista fiatalok körében. Orvosi hetilap, 2017, Vol. 158, No. 44, pp. 1754-1760, DOI: 10.1556/650.2017.30839

[138] Skultéti, D., Pikó, B. : Fiatalkori alkoholfogyasztás: a szocioökonómiai háttér és a szociális hatások szerepe. MentáIhigiéné és Pszichoszomatika, 2006, Vol. 7, No. 2, pp. 75-94, DOI: 10.1556/Mentál.7.2006.2.1

[139] Herpainé, L. J. : Three generation research concerning sport and value. In: Šimonek, J., Dobay, B. Mozgásban a sporttudomány: válogatott tanulmányok a konferenciáról. Komárno, Szlovákia : Univerzita J. Selyeho, 2018, pp. 274-280

[140]Kós, K., Herpainé, L. J. : A család szerepe az egészségkárosító szokások tükrében. Acta Universitatis De Carolo Eszterházy Nominatae: Sectio Sport, 2019, Vol. 46, pp. 57-69.

[141] Kovács, E., Pikó, B. : A család egészségvédő hatása serdülők körében= The protective influence of family among adolescents. Mentálhigiéné és Pszichoszomatika, 2009, Vol. 10 No. 3, pp. 223-237, DOI: 10.1556/Mental.10.2009.3.3

[142] Mikulán, R., Keresztes, N., Pikó, B. : A sport mint védőfaktor: fizikai aktivitás, egészség, káros szenvedélyek, In: Pikó, B. : Védőfaktorok nyomában. A káros szenvedélyek megelőzése és egészségfejlesztés serdülőkorban, Budapest, L'Harmattan (2010), pp. 115-130. 